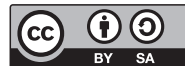

DOI 10.31261/IR.2020.05.12

Zinaida Gippius

1869-1945

Przylgnęło do niej kilka efektownych etykiet, z których "dekadencka madonna" była chyba najbardziej wyrafinowana. Za życia na jej temat plotkowano nader często, choć nie zawsze z elegancją. Zinaida Gippius przyciągała i odpychała, ceniono jej talent i drżano przed jej złośliwymi replikami. Dzisiaj należy do chętnie opisywanych $w$ literaturoznawstwie rosyjskim i obcym autorek Srebrnego Wieku.

"Tematem, który jak dotąd nie doczekał się opracowania, jest stanowisko pisarki w kwestii żydowskiej"1. Tymczasem — jak przekonująco dowodziła Temira Pachmuss - ta problematyka zajmowała ją stale. "Gippius zawsze interesowała się żydowską religią, żydowskim nacjonalizmem i 'misją' żydowskiego narodu, co wynika z jej dzienników i szeregu artykułów [...]"2. Po przewrocie bolszewickim wypowiadała się na te tematy z polemicznym zacięciem, a jej płomienny styl często "wywoł[yw]ał liczne protesty u czytającej publiczności na emigracji"”3.

Prezentujemy tutaj trzy artykuły Gippius poświęcone problematyce żydowskiej i antysemityzmu w przekonaniu, że również dzisiaj uświadamiają trudności, z jakimi żywe umysły minionego wieku walczyły z mentalnymi stereotypami Rosjan w kraju i na obczyźnie.

Pierwszy artykuł, zasadniczy i otwierający całą serię, nosi tytuł Antysemityzm? Został napisany w odpowiedzi na wypowiedź jakiegoś p. Szacha. Do tekstu, a może listu, będącego powodem polemiki Gippius, nie udało się dotrzeć, komentatorzy zagadnienia

1 I. Krycka-Michnowska, Żydzi i kwestia żydowska w prozie niefikcjonalnej Zinaidy Gippius, „Rusycystyczne Studia Literaturoznawcze", t. 27, Katowice 2017, s. 71.

2 Т. Pachmuss, Из архива Мережковских (I: Письма 3.Н. Гиппиус к И.А. Бунину. II: Письма Д.С. Мережковского к И.А. Бунину), "(ahiers du monde russe et soviétique” 1981, vol. 22, nr 4, s. 455.

3 Tamże. 
także pomijają go milczeniem ${ }^{4}$. Drugi artykuł — Jedyny pogromca - jest odpowiedzią na emigracyjne reakcje na Antysemityzm? W liście do Iwana Bunina z 4 lipca 1921 roku Gippius pisała: „Nie od Żydów [жидов], a od Rosjan otrzymuję odpłatę za mój artykuł. Jeden list z obelgami był nawet napisany na maszynie. Ech ty, taka-owaka (jak Boga kocham!), wynajął cię Burcew, żebyś broniła Żydów [жидов] za dobrą wierszówkę (to za to w "Obszczem Diele"!). Nie, widzisz, tyle się nacierpiałam, a Żydzi [евреu] i tak są niezadowoleni!"5. Zauważmy, że dla podkreślenia temperatury "obelg" pisarka posługuje się dwoma słowami na oznaczenie Żyda - pejoratywnym жид i neutralnym еврей. Trzeci artykuł Podoba się, czy nie podoba? zrodziła emigracyjna aktualność, niemniej Gippius podjęła w nim próbę pewnego podsumowania swojego stanowiska odnośnie do kwestii żydowskiej i antysemityzmu.

Jakie jest to stanowisko?

„W Antysemityzmie? - niechaj tłumacza wyręczy monografistka pisarki - Gippius twierdzi, że Rosjanie i Żydzi są jednakowo prześladowanym narodem, jednakowym w swoim nieszczęściu; że antysemityzmu nie było nie tylko w Wielkiej Rosji, ale i na południu Rosji, gdzie ludność żydowska i chrześcijańska współistniała bardzo pokojowo; że nie było antysemityzmu w armii rosyjskiej, a nawet w pierwszych dniach bolszewizmu. Jest tylko i zawsze była 'widzialność antysemityzmu', to znaczy postrzeganie antysemityzmu 'na górze, u naczelników, wodzów, władców'. W narodowej zaś Rosji nie ma i nigdy nie było antysemityzmu". W Jedynym pogromcy Gippius podtrzymuje swoje twierdzenie wyrażone wcześniej, że Rosjanie i Żydzi (w kraju i na emigracji) są sobie równi, połączyły ich łzy i krew, a "jedynym pogromcą" jest bolszewizm. Wreszcie w Podoba się, czy nie podoba? pisarka wypowiedziała w konkluzji znaczące słowa: „nam nie-Żydom, w zdecydowanej większości, ciąży nasze oderwanie od żydostwa, gdziekolwiek by było rozważane i gdziekolwiek by się objawiło: od głębokiego porządku religijnego, korzennego - po drobne, na poły barbarzyńskie przejawy życia codziennego".

Artykuły Zinaidy Gippius, czytane po niemalże stuleciu, z całą bezwzględnością ujawniają niezmienność napięć między Żydami i nie-Żydami. Iwona Krycka-Michnowska napisała: „Z publi-

4 Być może wytłumaczeniem tego pominięcia są zdekompletowane roczniki pisma w zbiorach bibliotecznych. Monografistka pisarki, Temira Pachmuss, dodaje, że w swojej polemice Gippius nawiązuje również do innych stanowisk, wyrażonych na łamach "Obszczego Dieła” — Dawida Pasmanika i autora ukrywającego się pod kryptonimem L.K. Jedynie o Pasmaniku wiemy więcej, pozostali polemiści pozostają nieznani.

Tamże, s. 420.

6 Tamże. 
cystyki i diarystyki Gippius wypływa nie tylko przekonanie o wzajemnej nienawiści Żydów i nie-Żydów, ale też głęboka potrzeba poszukiwania pojednania oraz wiara w możliwość jego urzeczywistnienia w przyszłości. Nadzieje na harmonijne współistnienie i przemianę ludzkości w braterską wspólnotę wiąże Gippius z ruchami religijnymi w Rosji, odrodzeniem Kościoła prawosławnego oraz otwarciem się Żydów na chrześcijaństwo. Antysemityzm i niemożność osiągnięcia autentycznej jedności między ludźmi, zdaniem pisarki, wynika z niedojrzałości chrześcijaństwa czy też braku religii, która prawdziwie spajałaby Stary i Nowy Testament"7.

Podstawa przekładu: Антисемитизм? „Общее Дело” [Париж] 1921, 24 czerwca, nr 343, s. 2-3 (wersja online: http://az.lib.ru/g/ gippius_z_n/text_1921_antisemitizm.shtml); Единый погромщик, „Общее Дело” [Париж] 1921, 2 sierpnia, nr 381, s. 2 (wersja online: http://az.lib.ru/g/gippius_z_n/text_1921_ediny_pogromschik. shtml); "Не нравится - нравится”, "Новый Корабль” [Париж] 1928, nr 4, s. 22-26 (wersja online: http://az.lib.ru/g/gippius_z_n/ text_1928_ne_nravitsya.shtml).

Marian Kisiel 


\section{ZINAIDA GIPPIUS}

Antysemityzm?

Jak ważne jest to, co dzieje się dzisiaj w Rosji, przekonują nas ci, którzy stamtąd się uratowali. Ale emigranci są głusi. Zajęci są szaleństwem osobistych sprzeczek. I chciałoby się milczeć, nie wchodzić w te swary, przeczekać ową falę, która - być może przejdzie.

Nie przyszłoby mi do głowy, aby odpowiadać na artykuł p. Szacha („Poslednije Nowosti”), chociaż jest on niemal wyłącznie skierowany przeciwko mnie, gdyby kwestia dotknięta przez autora nie była dzisiaj tak paląco pilna.

To - kwestia żydowska.

Pan Szach ujmuje ją w samej powierzchowności, zewnętrznej inscenizacji, czysto życiowo - więc i ja ją tak ujmę. Cytując fragmenty mojego Dziennika, w których wspominam Żydów (a nawet i te, gdzie wspominam nie Żydów, a Łotyszy i Litwinów), p. Szach pyta, po p i e r w s z e: czy inteligenci, którzy niedawno porzucili Sowdepię ${ }^{8}$, nie są już antysemitami, podobnie jak ci, którzy w niej pozostali? I p o d r u g i e: czy istnieje dzisiaj w Rosji, w szerokich masach, antysemityzm?

Drugie pytanie jest, rzecz jasna, poważniejsze. Postaram się odpowiedzieć na obydwa. Wiem, że wielu boi się jakiegokolwiek dotknięcia tego tematu. Spróbujcie tylko, mówią, wypowiedzieć słowo "Żyd”. Od razu będą was podejrzewać o antysemityzm. Wiem, że podejrzewać wszystkich o wszystko jest dzisiaj głównym zajęciem emigrantów. Ale to zjawisko jest głęboko nienormalne i byłoby upokarzające, gdyby się z nim liczyć.

Czy to normalne, aby, w istocie rzeczy, podejrzewać rosyjską inteligencję o antysemityzm? Na zdrowy rozum zdolny jest do tego tylko ignorant. $Z$ równą podstawą można by zarzucić tej

\footnotetext{
Sowdepia - historyczna, lekceważąca nazwa bolszewickiej Rosji, utrwalona przez jej przeciwników głównie na zachodzie Europy; skrót od совдеп — Совет Народных Депутатов.
} 
nieszczęsnej inteligencji... choćby szowinizm, czy cokolwiek innego. Nie, jeśli jest jakikolwiek punkt „świętości” w duszy rosyjskiego inteligenta - to jest on tutaj, w jego krystalicznie uczciwej relacji do Żydów. I tej uczciwości i czystości nie zniszczy niczyje oszczerstwo: ani bolszewika, ani partyjnego emigranta, ani najbardziej podejrzliwego z Żydów.

Tak było, i było to niezmienne, a teraz... teraz do tego doszło jeszcze coś nowego: poczucie pełni i naszej zewnętrznej równości z Żydami, naszej jednakowości w nieszczęściu. Kto po dziś dzień nie odszedł od starych, na skórze wybitych, przedrewolucyjnych siniaków i poglądów: "uciskany naród... pogromy..." itd. - ten przede wszystkim beznadziejnie nie rozumie rewolucji, uważa siebie za "lewicowca" lub "prawicowca"— bez znaczenia. My i Żydzi — czyż nie jesteśmy jednakowo uciskanym narodem? I czy nie jest to nasz wspólny — leninowski, wszechrosyjski — pogrom?

Ludzie prawdziwie głębocy, dzisiejsi Żydzi-antybolszewicy, od dawna krzywią się na te dawne "obrony". Czas, aby je odrzucić. Linia podziału jest inna. Bici Rosjanie, bici Żydzi są po tej samej stronie, są jednością. Bijący Rosjanie, bijący Żydzi są po drugiej, i także są jednością.

Jeśli ja, my i wszyscy inteligenci żyjący w Sowpedii, którzy z niej odjechaliśmy lub w niej pozostaliśmy, naprawdę należymy do inteligencji - odpowiedź na pierwsze pytanie p. Szacha jest oczywista. Ten, kto nie może być antysemitą, ten nigdy nie będzie mógł nim "stać się", a w obecnych warunkach jeszcze mniej niż kiedykolwiek.

Ale to drugie pytanie, bardzo ważne, dotyczące nieuświadomionych kręgów Rosji, a jej tłuszczy: czy jest dzisiaj antysemityzm w narodzie, w mieszczanach i nizinach chłopskich? Jaki jest stan na dzisiaj?

Ograniczywszy się zawczasu: po pierwsze, swoim doświadczeniem, własną obserwacją aż do roku 1920; po drugie, wszelkimi świadectwami, otrzymanymi przeze mnie od późniejszych rosyjskich wychodźców - odpowiadam następująco: antysemityzmu nie ma. Jest jego widzialność.

Antysemityzmu nie ma.

W narodzie rosyjskim, w jego charakterze, nie ma wcale skłonności do narodowej wrogości w ogóle, a do antysemityzmu w szczególności. Nigdy go nie było nie tylko w Wielkiej Rosji (to jeszcze można wyjaśnić tym, że mieszkańcy pozacentralnych guberni rzadko stykali się z Żydami), ale i nie było go też na południu. Kto zna przedwojenną Ukrainę, ten może zaświadczyć, że wspólnoty chrześcijańska i żydowska współżyły tam pokojowo. 
Nie było antysemityzmu również w wojsku, wśród żołnierzy, to znaczy - tych samych chłopów, zebranych z różnych krańców Rosji. Nie było nawet jego cienia w pierwszym okresie bolszewizmu. Kiedy komisarze przemawiali na mityngach w czasie owych miodowych miesięcy ludowego zachwytu nad „pokojem, chlebem i wolnością", mówili wówczas, jak na przykład Wołodarski ${ }^{9}$, z silnym żydowskim akcentem, i nikomu do głowy nie przyszło, żeby się dziwić, czy nawet odnotować, że mówi Żyd. Krzyczano tylko: Racja! Tak jest!

Podobnie jak wtedy nie było antysemityzmu, tak i nie ma go teraz. Ale wtedy nie był on też "widziany". Czymże jest więc ta „widzialność"? I skąd się ona bierze?

Na ile, uważnie obserwując, mogę to prześledzić: narodziny i narastanie nienawiści do komuny przypada na czas pojawienia się tej "widzialności” antysemityzmu. Obok głównej linii nienawiści zaczęła wić się również i ta, poboczna.

Jak ją objaśnić?

$\mathrm{O}$, tylko nie tym głupim przesądem, żałosnym i tępym oszczerstwem, że stworzona została przez rosyjskie "resztki", odpadki, kurz startego samodzierżawia; "przez wszystkich albo prawie wszystkich komisarzy - Żydów".

Chcę wyraźnie powiedzieć: jeśli wziąć procentowy stosunek, jeśli włączyć Niemców, Łotyszy, to także wtedy otrzymamy znaczącą większość - ro s y j k i c h komisarzy-komunistów.

Taka jest ogólna statystyka. Jest faktem. Ale obok jest inny fakt, czysto życiowy: wśród komisarzy-komunistów działających, kierujących, tych, którzy są „na widoku”, tych, z którymi najczęściej przychodzi stykać się miejskiej i wiejskiej demokracji — wśród nich, tak naprawdę, większość to Żydzi.

Jest to całkiem naturalne. Czy możemy silny, wytrwały naród, obdarzony cudowną energią, niosący w krwi pamięć długiego ucisku, porównywać z leniwym Ruskiem, a nawet carem „oświeconym"? Do tego wystarczy impuls „świerzbiącej ręki”, ale wytrwałości w tym nie ma.

Bolszewicy na próżno chcieli postawić "na widoku” tylko komisarzy Rosjan. Obcy okazali się bardziej niezawodni —

9 W. Wołodarski, właśc. Moisiej Goldstein (1891-1918), rosyjski rewolucjonista, komunista, komisarz prasy, propagandy i agitacji w pierwszym rządzie bolszewickim. Gippius pisała o nim: „'Wołodarski' to oczywiście pseudonim. Nazwisko tego Żyda brzmi albo Kogan, albo Goldstein (dwie wersje). Dawny krawiec z Łodzi, sam nauczył się pisania i czytania. U nas władał prasą. Zamknął wszystkie gazety, wściekle oskarżałje w trybunale, przysięgał, że 'wybije z rąk burżuazyjnych pismaków ich szabelkę '". Zob. Z. Gippius, Dzienniki petersburskie (1914-1919). Dzienniki warszawskie (1920-1921), przeł. H. Chłystowski, Warszawa, Czytelnik 2010, s. 334. 
bardziej fanatyczni, bardziej wydajni. Łotysz Peters ${ }^{10}$ i Polak Dzierżyński" ${ }^{11}$ są znani. Z nimi, z Żydami, można, oczywiście, porównać tylko Trockiego ${ }^{12}$ i Zinowjewa ${ }^{13}$. Łotyszy i Polaków jest całkiem sporo na „widocznych” miejscach, a jeśli Żydów jest więcej, to dlatego, że jest ich w ogóle więcej. A teraz, każdego dnia, stykając się ze znienawidzoną komuną w osobie jej widocznych przedstawicieli, nierozsądny mieszkaniec Sowdepii (nie rozstrzygniesz, kiedy skóra została zdarta!) tworzy przy pomocy skojarzeń niezwykle powierzchowny „antysemityzm”. Wyraża się on w bezsilnym głuchym wyzwisku — przeciwko komisarzom... których wszakże nie nazywa się częściej „Żydami"14 niż „szatanami”, a Lenina „Tatarzynem"15.

Powtarzam: jest autentyczny antykomunizm i antykomisarstwo. Nie ma autentycznego antyżydostwa, ponieważ nigdy go nie było.

Przychodziło mi się stykać z obawami przed jakimś wielkim żydowskim pogromem, stale rosnącymi. Co za bzdura! Prawdopodobny jest inny pogrom - komunistyczny. Jest prawdopodobny i to go czyni prawdopodobnym, im dłużej panują bolszewicy. Ale i w tym strasznym przypadku (każdy pogrom jest straszny) przyjdzie nam zostawić nasz szczególny lęk o Żydów.

10 Jakow Peters (1883-1938), rewolucjonista, komunista, zastępca Feliksa Dzierżyńskiego, w WCzK jeden z największych sadystów. Gippius nazywała go „bezlitosnym” . Zob. Z. Gippius, Dzienniki petersburskie..., s. $376,392$.

11 Feliks Dzierżyński (1977-1926), polski socjaldemokrata i rosyjski komunista, po Rewolucji Październikowej należał do ścisłego kierownictwa państwa, był twórcą sowieckiego aparatu terroru, kierował jej organami bezpieczeństwa. Gippius nazwała go „literalnym katem”. Zob. Z. Gippius, Dzienniki petersburskie..., s. 334.

12 Lew Trocki, właśc. Lejba Bronstein (1879-1940), rewolucjonista, komunista, twórca teorii permanentnej rewolucji (теория перманентной революции), jeden z twórców państwa radzieckiego i Armii Czerwonej. Po śmierci Lenina toczył walkę o władzę z Józefem Stalinem. W 1929 roku został pozbawiony praw obywatelskich, deportowany z kraju. Został zamordowany na rozkaz Stalina. Gippius w dziennikach pisała o Trockim (najczęściej używając jego prawdziwego nazwiska): „Nawiązanie z nim kontaktu to, pomijając obrzydzenie, rzecz równie bezcelowa, jak wszczęcie rozmowy z jakąś małpą". Zob. Z. Gippius, Dzienniki petersburskie..., s. 215.

13 Grigorij Zinowjew, właśc. Owsiej-Gerszen Radomyslski, także: Hirsz Apfelbaum (1883-1936), rosyjski rewolucjonista, komunista, członek ścisłego kierownictwa władz bolszewickich, w latach 1919-1926 przewodniczący Kominternu. U progu wielkiego terroru stracony po procesie pokazowym. Gippius tak go scharakteryzowała: „To człowiek tłusty, o białej skórze, kędzierzawy. Na fotografiach w gazecie przypomina do złudzenia pulchną starą ciotkę. Zimą i latem bez czapki. Kiedy jedzie swoim automobilem — otwartym — dodaje sobie wzrostu na kolanach dwóch czerwonoarmistów. To jego osobista ochrona. Bez niej ani kroku — tchórz pierwszej wody". Zob. Z. Gippius, Dzienniki petersburskie..., s. 387.

14 Gippius pisze: жидами, odwołując się do obraźliwego w języku rosyjskim znaczenia słowa Żyd.

15 Władimir Lenin, właśc. Uljanow (1870-1924), założyciel partii bolszewickiej, ideolog komunizmu. Przywódca Rewolucji Październikowej i twórca pierwszego na świecie państwa socjalistycznego, Rosji sowieckiej. „Tatarzyn” — aluzja do Symbirska, miejsca urodzenia Lenina, z liczną mniejszością czuwaską i tatarską. W dziennikach Gippius nazywa go także "Triszką", czyli uosobieniem takiego zła, które przywołał Iwan Turgieniew w Zapiskach myśliwego. Zob. Z. Gippius, Dziennikipetersburskie..., s. 114, 136. 
Zginie, rzecz jasna, wielu niewinnych, ale bez różnicy narodowości. Zginą winni, to znaczy komuniści. Jeśli przypomnimy teraz naszą ogólną statystykę, to przekonamy się, że Żydów mimo wszystko zginie znacznie mniej niż Rosjan. Linia separacji tak się zarysowała, szła i pójdzie: ale nie według znaków narodowości, a według stopnia uczestnictwa w bolszewickim ruchu.

Należy to w końcu zrozumieć i zaakceptować: naszą rzeczywistą równość z Żydami. Winny jest jednakowo winny, czy jest Żydem, czy nie jest Żydem. Niewinny jest jednakowo niewinny, czy jest Żydem, czy nie jest Żydem.

Rosyjski naród to rozumie. I ma całkowitą rację.

Mogą mi wszakże powiedzieć: jeśli tak niewiele jest skłonności w charakterze rosyjskim do antysemityzmu, to skąd pogromy? Nawet teraz, w ostatnim czasie... Na południu dowiedziono przypadków, kiedy w miejscowości, wyzwolonej od bolszewików, dokonała się zagłada ludności żydowskiej. Skąd to?

Stąd, skąd i za cara. Jeśli nie całkowicie z tego samego powodu, to częściowo - zapewne. Przypomnijmy sobie, jak tłumaczyliśmy sobie pogromy za cara. Czy nie widzieliśmy, że były kierowane z gó ry? W narodzie rosyjskim jest jedna szczególna cecha, którą należy uznać: to jego niezwykła podatność na wpływ odgórny. Nie na darmo mówimy: "jaki pop, taka parafia” (po europejsku należałoby powiedzieć odwrotnie: jaka parafia - taki pop). Pogrom za samodzierżawia był konsekwencją antysemityzmu "na górze”. Pogrom dzisiejszy - podobnie, może być tylko następstwem istniejącego antysemityzmu "na górze", u naczelników, wodzów, władców. Ale obecnie jest on tylko bladym cieniem tamtego, albo neutralnie, a nie jaskrawo wyrażonym sprzeciwem wobec pogromów. Poza tym... co my wiemy? Które z tych pogromów były rzeczywiście żydowskie, a które mieszane, to znaczy były po prostu dziko nieokiełznanymi grabieżami tych, którzy wpadli pod rękę. Naród dawno ogłupiał od krwi, ucisku i głodu. Sam wie, że ogłupiał. Byli w tym miejscu Żydzi - zabici, rozgrabieni Żydzi. Na przykład bandy działające na południu: ich przywódcy nie wiedzą, co to ancien régime (znają tylko grabież). Jednakże i tam są "pogromy": tam już W sposób jawny Żydów się niszczy, jak tylko "wpadną pod rękę".

Naród wszelako zaczyna wychodzić ze swojego szaleństwa. I choć na głębinach tego szaleństwa wcale nie był antysemitą - to nie powróci, zmartwychwstawszy, obcą mu nienawiścią do Żydów. I jakikolwiek rząd pojawiłby się w Rosji po upadku obecnego, przemocowego i destrukcyjnego, będzie on (tj. warunki jego funkcjonowania) zbliżał się do narodu i, w konsekwencji, nie będzie antysemicki. 
Mam jeszcze podstawę twierdzić, że bliskie odrodzenie narodu będzie oryginalne i, przy tym, wolne od jakiejkolwiek narodowej nienawiści. Tą podstawą jest charakter dzisiejszego rosyjskiego ruchu religijnego. Nie wszyscy wiedzą, że w Cerkwi rosyjskiej nastąpił podział, swego rodzaju rewolucja, i że wszyscy znajdujemy się jakby na początku reformacji. Jest to wszakże faktem. To temat bardzo ważny, przyjdzie o nim pomówić osobno. Tutaj powiem tylko tyle, że nowy ruch narodowo-religijny na tyle jest niebezpieczny dla bolszewików i dla monarchistów, na ile błogosławiony dla narodu rosyjskiego i łaskawy dla Żydów: niesie z sobą ożywczy pokój, a nie nacjonalistyczną nienawiść.

A zatem, reasumuję moje stanowisko, oparte na doświadczeniu i rozsądku prawie wszystkich, którzy Rosję niedawno opuścili i nie oderwali się od niej. Wszystkich należących do rosyjskiej „partii bezpartyjnych”, z jej bardzo wyraźnym programem i nie mniej wyraźną taktyką (w końcu — myślę, że ta partia jest teraz w Rosji najliczniejsza, a w przyszłości będzie "najpotężniejsza").

W odniesieniu do kwestii żydowskiej potwierdzamy: w ludowej Rosji nie ma obecnie antysemityzmu, podobnie jak nie było go nigdy. Ta "widzialność" antysemityzmu jest wąska, blada, powierzchowna i w żadnym wypadku nie może wywołać żydowskich pogromów po upadku bolszewików, bez względu na to, jak bardzo by się zasiedzieli. Opóźnienie tego upadku może tylko przynieść komunistyczną porażkę, i to w bardzo niepożądanych rozmiarach.

A w końcu: podejrzewać inteligentów, którzy uciekli z Rosji i pozostali w Rosji, że są " antysemitami”, można tylko w przypadku ignorancji lub bezmyślności. Jednak fakt takich i podobnych wzajemnych podejrzeń, szeroko praktykowany wśród naszej nieszczęsnej emigracji, być może da się również wytłumaczyć trudnym jej stanem moralnym. Rosyjscy uchodźcy są zagubieni, rozjuszeni, zażarci. Podobnie jak "obłąkani nędzarze”, zasługiwaliby nawet na wyrozumiałość, gdybyśmy... gdybyśmy nie wiedzieli, że są inni, przerażająco bardziej prawdziwi „szaleni nędzarze", inteligenci w Sowdepii, którzy nie cierpią jak emigranci — i nadal zachowują w duszy iskrę człowieczą. Nie podejrzewają się wzajemnie, jak emigranci, ani o ludożerstwo, ani o żydożerstwo, ani o monarchizm, ani... o co jeszcze? Niechby i nie wiedzieli lepiej o sprawach emigracji. A nuż będziemy mieli tutaj okazję, by się opamiętać, pohamować, wspomnieć choćby tych, którzy pozostali - i o Rosji. 
Trudno jest dzisiaj mówić o czymkolwiek innym niż o nieszczęściu pochmurej Rosji. I skądkolwiek by zaczynać rozmowę, jakąkolwiek poruszać kwestię - zawsze wracamy do tego samego. Pozwolę więc sobie przypomnieć kilka wierszy z mojego niedawnego artykułu Antysemityzm?, opublikowanego w "Obszczem Diele”.

W artykule tym dowiedziono rzeczy następującej: lud rosyjski w istocie swojej nie jest skłonny do narodowej wrogości w ogóle, a do antysemityzmu w szczególności. W tej chwili w Rosji ludność rosyjska i ludność żydowska są sobie równe głębokością przeżytych bied, ponieważ są jednakowo prześladowane przez wspólnego wroga ojczyzny - komunistyczną władzę. Ostatnie pogromy, opisywane jako żydowskie, prawdopodobnie są "mieszane": są to pogromy rozpaczy — tych, kto wpadł pod rękę. Jeśli możliwy jest jakikolwiek pogrom w najszerszych rozmiarach, to tylko pogrom "komunistyczny"; cała wrogość i nienawiść ludności rosyjskiej zwrócona jest wyłącznie w stosunku do nich, komunistów, do tego rządu — bez różnicy narodowości.

Przypomnijmy dwie depesze (z ostatnich dni). Pierwsza: ludność „w całej Rosji ogarnięta jest paniką... ucieka w stronę granicy... nie zważając na represje ze strony sowieckich władz pogranicznych, gromadzą się tam dziesiątki tysięcy uciekinierów. Ich położenie jest straszne... ludzie są dosłownie nadzy... prawie wszystkie dzieci do lat siedmiu umarły z głodu..."

I druga, po kilku dniach: „Dziesiątki tysięcy mieszkańców biegnie w stronę polskiej i rumuńskiej granicy. Przebiwszy się przez sowiecką straż, masy rozłożyły się obozem na granicy Polski, do której ich nie wpuszczają. Sytuacja jest nie do opisania. Ludzie są w samych koszulach, chorzy, umierają setkami, właśnie tu..."

Wystarczy. Wszyscyśmy to czytali. Przywołuję te dwie depesze tylko dla porównania. Ale jak je porównywać? Słowa nawet pasują. Mówią o jednym i tym samym. Czy o jednych i tych samych ludziach? Nie, tylko o ludziach takich samych, nierozróżnialnych w nieszczęściu. Dlatego, że pierwsi, są z raportu dr. Krejnina ${ }^{16}$, który dopiero co „z wielkim trudem, prawie że rozstrzelany, wyrwał się z sowieckiej Rosji". (Dokładnie tak samo, jak wyrwali się

\footnotetext{
${ }^{16}$ Miron Naumowicz [Meer Menachimowicz] Krejnin (1866-1939), prawnik, działaczspołeczny, współtwórca żydowskiej partii narodowej Folkspartei (1906). W 1918 został wybrany wiceprzewodniczącym Rady Gmin Żydowskich w Rosji. Od 1921 na emigracji — najpierw w Berlinie, potem w Paryżu. Od 1925 roku przewodniczący Emigdirekt, zjednoczonego komitetu emigracji żydowskiej w Europie. Od 1934 roku mieszkał w Erec Izrael, umarł w Jerozolimie.
} 
nieżydowscy, rosyjscy działacze społeczni — nie bolszewicy. I tutaj jest pełna równość). Ten pierwszy komunikat jest tylko o Żydach. Drugi jest zwykłą dziennikarską wiadomością o Rosjanach.

Wywód jeden, wspólny dla jednych i drugich: ludzie masowo ruszyli, bezustannie idą od śmierci — do śmierci...

Dr Krejnin odnotowuje pogromy ludności w miejscowościach... zasiedlonych przez Żydów. Tam pogromy, rzecz jasna, będą „żydowskie". Jednakże ten sam dr Krejnin nie ukrywa, że pogromy dzieją się i na Powołżu, na północy, gdzie "rozgromiono nawet kolonie niemieckie". Jest mało prawdopodobne, żeby ostatnie pogromy przypisać antysemityzmowi.

Że "gromi i armia Budionnego, i komuniści" — wiedzieliśmy od dawna; lecz kogo "gromi"? Żydów? I tamtejsi chłopi działają razem z komunistami? W to nigdy nie uwierzymy. Chłopi nigdy nie będą z komunistami zajedno ${ }^{17}$, ani po tej samej stronie - nawet w momencie grabieżczego szaleństwa.

A oto jeszcze jedna niedawno opublikowana wiadomość, bardzo charakterystyczna: będące poza wszelką kontrolą, narastające mordowanie Chińczyków. Rzecz zaskarżono na Kreml i doprowadzono nieomal do specjalnego dekretu. Jakże więc, czyż nie budzi się w Rosji antychińskość?

$\mathrm{Nie}$, to wszystko jest tym samym, naprawdę strasznym, naprawdę rosnącym - a n t y k o $\mathrm{m}$ u $\mathrm{n}$ i z $\mathrm{m}$ e $\mathrm{m}$. A jeśli on jest to, zaprawdę, nie ma ani Greka ni Żyda ${ }^{18}$, ani Rosjanina ni Chińczyka. Jesteśmy tylko my — ludzie; i oni — bolszewicy, "diabły”.

Mówię, oczywiście, nie o jakiejś IV Międzynarodówce, nie odrzucam tożsamości narodowej, nie chcę powiedzieć, że narody Rosji zespoliły się, stały jednakowe (niezręcznie jest się oczerniać, ale, jak się zdaje, trzeba). Nie, naród żydowski ma swoje "oblicze"; rosyjski ma także swoje, inne. Nie są jednakowe, i dobrze. Mówię nie o podobieństwie, biorę zwykłą i palącą kwestię naszej ró wn ości, dzisiaj, w obliczu jednego nieszczęścia, jednego wroga - i jedną naszą odpowiedzialność przed jedną wspólną ojczyzną — Rosją.

I tutaj powiem zwyczajnie: my, Rosjanie, mocniej i głębiej odczuwamy równość z Żydami niż Żydzi z nami. Nie rozdzielamy się, nie możemy. Wołając o pomoc dla ginących mieszkańców Rosji - żaden Rosjanin nie odróżnia Rosjan od innych, ciepiących tam narodowości, nie myśli (po prostu nie przychodzi mu to do głowy), że jest zobowiązany pomóc najpierw Rosjanom, a potem wszystkim innym. Tymczasem wielu (nie powiem, że wszyscy)

\footnotetext{
17 „Zajedno”, archaizm użyty tu w znaczeniu: wspólnego działania, bycia w sojuszu.

18 Kol 3,11.
} 
działaczy żydowskich, jak gdyby odizolowuje swój naród, wyodrębnia go $z$ całej masy jednakowo ginących. Na linii podziału tego, co nadnarodowe, szeregowy Żyd nie posiadłjeszcze tej twardości, do której myśmy doszli. Zupełnie to niezrozumiałe... Ale fakt równości jest faktem obiektywnym, mądrość wymaga, by wziąć to pod uwagę, i nawet mądrość jest praktyczna.

$\mathrm{Na}$ zakończenie jeszcze jeden malutki przykład, całkowicie utwierdzający mnie w moim głównym przekonaniu, że narodowi rosyjskiemu, jako całości, w jego zdrowym jądrze, antysemityzm jest obcy. To reguła, a każdą regułę potwierdzają wyjątki. Wyjątki otrzymałam pod postacią listów Anonimów w odpowiedzi na mój artykuło kwestii żydowskiej. Piszą wszyscy Rosjanie — nieszczęsne jednostki - zagubione tutaj i same siebie gubiące. Monotonnie obruszają się na mnie z powodu mojej „obrony” (?) Żydów. (Jeden z nich nawet mi grozi i używa słów, których nie można wydrukować. Oto różnica: trudno sobie wyobrazić, żeby Żyd mógł napisać taki list) ${ }^{19}$. Jakiś "dżentelmen" z Anglii, wyraziwszy wątpliwość, czy i ja przypadkiem nie należę do narodowości żydowskiej (w nawiasie dodawszy: "Któż Panią zna?"), nagle zakończył: „Nie jestem monarchistą, ale socjalistą. I teraz, pozostając czystym socjalistą, jestem — antysemitą..."

W Anglii, być może, rosyjski uciekinier, zagubiwszy siebie, i do takiego absurdu może dojść.

Ale nawet te nieszczęsne "wyjątki" — jakimż są oni pogromcami? Anonimowo wzajemnie się obrażać, chwalić się z pozycji wybitnego umysłu rosyjskim brakiem kultury - tak czy siak można. Nie ma w tym nic strasznego. Jeden jest u nas pogromca, jeden i ten sam - i u nas, Rosjan, i u was, Żydów. To kapral Budionny ${ }^{20}$, to Polak Dzierżyński, to Żyd Lew Bronstein, to Rosjanin Władimir Uljanow ze swoim doradcą i innym, rosyjskim pisarzem Aleksiejem Pieszkowem ${ }^{21}$. Czyż mało jeszcze nosi nazwisk ten

19 Zob. list do Iwana Bunina, w: T. Pachmuss, Из архива Мережковских (I: Письма 3.Н. Гиппиус к И.А. Бунину. II: Письма Д.С. Мережковского к И.А. Бунину), w: „Cahiers du monde russe et soviétique” 1981, vol. 22, nr 4, s. 420.

20 Siemion Budionny (1983-1973), kawalerzysta, dowódca 1 Armii Konnej, marszałek Związku Radzieckiego, zaufany Stalina. Gippius używa tutaj słowa yнmep (podoficer; był nim w czasie I wojny światowej), choć po rewolucji bolszewickiej Budionny dowodził już armią.

${ }^{21}$ Maksym Gorki, właśc. Aleksiej Pieszkow (1868-1936), pisarz rosyjski, jeden z najwybitniejszych twórców Srebrnego Wieku. Zaprzyjaźniony z Dzierżyńskim i Leninem, był przeciwny rewolucji 1917 roku i angażował się w obronę aresztowanych przez bolszewików pisarzy. W latach 1921-1927 przebywał na emigracji, po powrocie do Rosji włączył się w propagowanie realizmu socjalistycznego. W dziennikach petersburskich Gippius nazywa go „cierpiętniczym kretynem” i przytacza swoją z nim rozmowę. Na słowa Gorkiego: „Organicznie... nie mogę... rozmawiać z tymi... łajdakami. Z Leninem i z Trockim”, pisarka zareagowała następująco: „żadne, powiadam artykuły [...] nie odgrodzą pana od bolszewików, 'łajdaków', wedle pańskich słów; powinien pan odejść z tej kompanii”. Gorki miał odpowiedzieć: „A jeśli. . . odejść. .. to z kim być?". Zob. Z. Gippius, Dzienniki petersburskie..., s. 241, 219. 
jedyny pogromca? Przeciwko niemu — za życie naszych bliskich, za nasze życie - chcemy i powinniśmy pójść do boju, ręka w rękę z narodem żydowskim. Jesteśmy sobie równi, jesteśmy braćmi: łzy i krew połączyły nas w jedno.

\section{Podoba się, czy nie podoba?}

W Paryżu odbyła się niedawno debata $O$ antysemityzmie $w$ sowieckiej Rosji22. Tytuł nietrafiony. Co można wyjaśnić, gdyby trzymać się blisko tematu? Tylko potwierdzić, że owszem, rosyjscy robotnicy prześladują rosyjskich Żydów, gdzie jest to możliwe ścigają ich i brutalnie męczą; i uznać, że jest to złe. Zawsze, rzecz jasna, jest źle, kiedy jedni męczą i ścigają innych; ale dlaczego ścigają właśnie Żydów - tego właśnie nie można wyjaśnić przy tak wąskim zakreśleniu problemu. „Antysemityzm” absolutnie niczego nie tłumaczy. Tym bardziej, że i to słowo jest wymyślone, jak mi powiedział pewien Żyd. Przecież wykorzystujemy je w znaczeniu "antyżydostwa”, prześladowania „Żydów”, ale już nie "Semitów" w ogóle, Arabów na przykład czy Ormian. Kwestia żydowska nie przekłada się na kwestię wzajemnych relacji ras. Istnieje ona w jakiejś swojej osobliwości, właśnie jako k w e s t i a żydowska.

Debata częściowo przerodziła się w debatę na temat "kwestii żydowskiej", chociaż utrudniały ją z dawna utarte poglądy i utarte znaczenie będącego w użyciu słowa "antysemityzm".

W odpowiedzi na debatę p. Poliakow-Litowcew słusznie powiedział, że dobrze byłoby kiedyś zebrać razem Żydów i Rosjan (czy w ogóle nie-Żydów) i otwarcie wzajemnie porozmawiać: wy, dajmy na to, dlatego a dlatego się nam nie podobacie; a w was nam się to i to nie podoba ${ }^{23}$. Tak, taka dysputa, czy takie dysputy, wiele by korzyści przyniosły obu stronom, wiele by także pomogły w wyjaśnieniu kwestii. Wszak ona istnieje, jakkolwiek byśmy próbowali się od niej odwrócić. Dlatego tak zwany „antysemityzm”

22 Gippius ma tu na myśli debatę Kryzys żydowskiej kolonizacji w Rosji, zorganizowaną 11 lutego 1928 roku przez Związek Studentów-Syjonistów z Imperium Rosyjskiego (Союз студентов-сионистов из Российской Империи), utworzony w Paryżu przez Elie Eberlina (1875-?), działacza syjonistycznego i dziennikarza.

23 Sołomon Poliakow-Litowcew (1875-1945), pisarz i dziennikarz, od 1910 przebywający w Paryżu. W latach 1921-1922 redagował berlińskie pismo "Głos Rosji” („„Голос России"). Gippius odwołuje się do stanowiska zaprezentowanego w artykule: С. Литовцев, Диспут об антисемитизме. "Последние новости" [Париж] 1928, nr 2624, s. 2. 
nie znika ze świata, nie jest leczony żadnymi "humanistycznymi” i "kulturalnymi” środkami. Być może nie należy przykrywać tej dziwnej o b c o ści (czy ró ż n i c y) między Żydami i nie-Żydami, która przecież wciąż istnieje? Być może trzeba, na odwrót, mężnie dokopać się do jej korzeni, wspólnie dociec, co właśnie nas dzieli, dlaczego rozdzieliło? A co, jeśli wtedy szeroko otwartymi oczami zobaczymy i sens tego rozdzielenia, to znaczy tę jego prawdę, która może przywieść nas do jakiegoś całkiem nowego złączenia?

Nikt nie będzie się spierał co do tego, że korzenie "kwestii żydowskiej" są religijne. Nikt nie będzie twierdził, że nawet i my całkiem oderwaliśmy się od tych korzeni; a już Żydzi — nie mniej. (Mówię nie tylko o ludziach "religijnych", ale i „świadomie” niereligijnych, o wszystkich; historia Europy i Azji jest we krwi każdego. U Żydów więcej niż u kogokolwiek). Jeśli zaś liczyć się z korzeniami - trzeba zacząć od korzeni.

Ale tutaj od razu zobaczymy, że otwarta i pożyteczna pierwsza rozmowa miedzy Żydami i nie-Żydami (wedle propozycji Poliakowa-Litowcewa), poniekąd jest nie do zrealizowania. Nie-Żydzi (chrześcijanie prawdziwi lub choćby pochodzący od przodków chrześcijan) będą mówić z Żydami o tym, co się im w nich podoba, co zaś nie podoba; w każdym razie, jest to wyobrażalne. Ale Żydzi, zarówno ci którzy nie utracili, jak i ci, którzy utracili wiarę przodków - na nic podobnego nie pójdą. I już to jedno pokazuje, jak mało oderwani są Żydzi od swoich korzeni (i jak ważne, badając kwestię, jest liczenie się z korzeniami, a nawet od nich zaczynanie).

Albowiem milczenie Żydów o sobie w ogóle i o sobie w stosunku do nie-Żydów to oddźwięk ich ś w i ę t e g o milczenia, dawnego prawa starożytności, niepozwalającego wymieniać imienia Boga. Dzisiaj Żyd, choćby był słabo religijny, lecz jeśli jest mimo wszystko Żydem, jest też p o b o ż n y. Pobożności nie ma, ale pobożność w nim pozostaje, własna, szczególna, w żaden sposób niepodobna do pobożności chrześcijańskiej u chrześcijan (którzy, nawiasem mówiąc, kiedy przestają być prywatnie chrześcijanami, już nie zachowują swojej pobożności).

Żydowska, specyficzna pobożność zamąciłaby w otwartej rozmowie o wzajemnych relacjach, n a w e t gdyby nie dotyczyła po prostu korzeni żydowsko-nieżydowskiego rozdziału, to znaczy początków religijnych. Tym bardziej - gdyby została

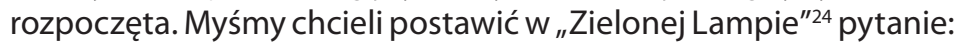

24 "Zielona Lampa” (1927-1939), towarzystwo literacko filozoficzne założone z inicjatywy Gippius, mające na celu integrować intelektualne środowiska rosyjskie na emigracji i wpływać na rozwój kultury. Zebrania odbywały się raz w tygodniu w paryskim salonie Mereżkowskich przy rue Colonel Bonnet. 
dlaczego Chrystus nie jest dla Żydów Mesjaszem? Kwestię tę można by zobaczyć również $w$ aspekcie historycznym. Lecz szybko zrozumieliśmy, że nic z tego nie będzie. Wszyscy Żydzi, wierzący i niewierzący, będą milczeć.

Otwarta debata - "co nam się w sobie podoba, a co nie" jest dlatego do wyobrażenia tylko jednostronnie, to znaczy już nie jako debata, a jako wypowiedź nie-Żydów na temat tego, co w Żydach się im „podoba i nie podoba”. Mieliśmy już takiego "dyskutanta", takiego poszukiwacza cechy separującej nie-Żydów od Żydów. Poszukiwacza bardzo "korzennego", choć nieograniczającego się wyłącznie do korzeni. Tak często i tak żywo wypowiadał się na temat tego, co "podoba się" u Żydów (przyciąga), a co "nie podoba” (odpycha), że daj Boże każdemu. To Wasilij Rozanow ${ }^{25}$, oczywiście. Gdziekolwiek by i kiedykolwiek by pojawiało się pytanie o żydostwo - nie można nie wspomnieć Rozanowa. Trzy ćwierci jego pism poświęconych jest temu właściwie, co "podoba się" i co "nie podoba się" w Żydach. Odróżnieniu ich od nie-Żydów i nawet niejakiej „polaryzacji”. Przywołam tutaj dwa, trzy krótkie cytaty.

Patrząc z zewnątrz - są to najzwyklejsze sprzeczności. Lecz kto może, niech będzie uważny. Coś sobie uświadomi. Przecież Rozanow, mimo swojego geniuszu, jemu jednemu w pełni właściwego, jest bardzo charakterystyczny, wyrazisty, w znaczeniu własnego nieżydostwa. Z krwi dziedzicznej, $w$ całej swojej istocie jest on arcy-Aryjczykiem (nawiasem mówiąc, również arcy-Rosjaninem; nie ma $w$ nim ani jednej nierosyjskiej żyłki). Wszyscy wiedzą, jak nie tylko ciągnął do Żydów, ale najzwyczajniej w nich ugrzązł, przenikał do nich z miłością, wchodził w samą istotę żydowskiego bytu. Jakoś żywiołowo całkowicie religijny, Rozanow ateistami "gardził, nienawidził ich i bał się ich". Mówił: „Rozstaję się z nimi wiekuistym rozstawaniem" [„Расстаюсь с ними вечным расставанием"]. Tymczasem w jego mniemaniu nie ma ani jednego Żyda ateisty, ani jednego, cokolwiek by tam on o sobie myślał czy sobie wyobrażał. Rozanow był otoczony Żydami i, jak się zdaje, oni go też lubili. Skąd więc nagle, na długo przed wojną, bez najmniejszego powodu, wyrwały się mu takie dziwne słowa:

„'Usługi' żydowskie są jak gwoździe w moich rękach, serdeczność żydowska jest jak parzący mnie płomień. Ponieważ korzystając

25 Wasilij Rozanow (1856-1919), filozof, pisarz, eseista. Autor licznych książek, znanych również w przekładzie polskim, m.in. Ciemne oblicze (1911), Odosobnione (1912), Opadłe liście (1913-1915), Apokalipsa naszego czasu (1918). Gippius poświeciła mu szkic Zadumany wędrowiec („0kno” 1923, nr 4), przedrukowany później w jej książce Żywe twarze (1925). 
z owych usług, zginie mój naród, ulegnie zagładzie, ponieważ owiany ową serdecznością mój naród udusi się i zginie"26.

Mówiąc wprost: jest to najzwyklejszy antysemityzm, nieprawdaż? Czy nie było to wydrukowane w Nowych Czasach? Nie, nie. Również i takie twierdzenia odrzucam. Również i w tamtym czasie nikomu by do głowy nie przyszło, że Rozanow "stał się" antysemitą. Nie stał się nim. Swoją książką Ciemne oblicze, wprost wymierzoną w Chrystusa, płomiennie bronił się, zasłaniając Biblią, żydostwem, po którego stronie stał, jakby zlewając się z nim.

Dla Rozanowa, w tej książce, Chrystus nie jest Mesjaszem; jakimż jest on Mesjaszem, kiedy twierdzi, że jest niszczycielem, „który spadł z nieba jak błyskawica”... Ale czy stosunek Rozanowa do Chrystusa, tego fałszywego mesjasza, łączy się, zbiega ze stosunkiem żydowskim? Tutaj znowu sięgamy do korzeni; korzenie Rozanowa, nie-chrześcijanina, tkwią w historii chrześcijaństwa. I takie jest jego "doświadczenie” (cały jest doświadczony, każda jego myśl przechodzi przez doświadczenie, i to jest szczególnie cenne).

„Jakżeż zamlaskali z zachwytu zarówno 'idealista' Baruch i 'taka miła' Rebeka Ju-na, 'przyjaciółka naszego domu', kiedy przeczytali Mroczne oblicze ${ }^{27}$. Natychmiast powiedziałem sobie: 'w tył zwrot! bój się!' (mój stosunek do Żydów).

Myśleli, że nie widzę: ale chociaż 'wiecznie śpię', to jednak podpatrzyłem. St-er (Baruch), wyskakując z sań, z taką energią, wesoło, szczęśliwie, wykrzyknął, jak gdyby przekazując mi sekretną myśl i zakażając sobą:

- A jednak - to kłamca.

Nawet się przeraziłem. A Rebeka mówiła u Szury w pokoju:

‘Noooooo... tak... Przeczytałam Mroczne oblicze'. I znowu takie szczęście w ustach. Jak gdyby zjadła coś słodkiego" 28.

Wiecznie, na sposób rosyjski, wszystko wyolbrzymiający Rozanow - również tutaj, być może, przesadza. Ale przecież ogląda korzenie, z głębin ciągnie nić. Wypatrzył coś z prawdy. Nie zaakceptował, "nie spodobało mu się to”, odnotował jako linię separacji. Przecież to nie Mesjasz, wszak On również, według

26 В.В. Розанов, Опавшие листья. Короб первый, тип. т-ва А.С. Суворина - «Новое время», СанктПетербург 1913, s. 428 [przekład polski: W. Rozanow, Opadłe liście, przeł. J. Chmielewski, I. Kania, Biblioteka kwartalnika Kronos, Warszawa 2013, s. 173; przekład tego fragmentu Jacka Chmielewskiego].

27 W Polsce książka ukazała się pod tytułem Ciemne oblicze. Zob. W. Rozanow, Ciemne oblicze. Metafizyka chrześcijaństwa, przeł. H. Paprocki, Warszawa, Eneteia Wydawnictwo Psychologii Kultury 2006.

28 В.В. Розанов, Опавшие листья..., s. 428 [przekład polski: W. Rozanow, Opadłe liście..., s. 38; przekład tego fragmentu Jacka Chmielewskiego]. Mowa o członku Towarzystwa Religijno-Filozoficznego Borysie Grigoriewiczu Stołpnerze (1871-1937) i Rebece Julijewnie Efros, żonie krytyka i tłumacza Abrama Markowicza Efrosa (1888-1954). 
Rozanowa, przeciwko Bogu Stwórcy wystąpił, z którego starych przymierzy wyrósł Izrael... Wyrosło żydostwo. Czy nie ma prawa nienawidzić? Okazuje się, że nie. Okazuje się znów, według Rozanowa, że ta nienawiść jest wspólna (jeśli ona w ogóle jest). Dodajmy dla sprawiedliwości: Rozanow, jeśli nie tak samo, to inaczej, bardziej, częściej „lękał się" równieżchrześcijan, u których wich najbardziej chrześcijańskiej pobożności „podejrzewał” nienawiść do Boga Izraela, do tego, którego Jezus Izraelita nazywał Ojcem...

Żydzi „nie wypowiadają się", milczą. Nie-Żydzi, choćby przez usta Rozanowa, podglądają i odzywają się. Niezwykły geniusz Rozanowa w tych podglądaniach i wypowiadaniach, stawia nas w sytuacji, żeby jeszcze poważniej do nich się odnieść. A przecież nie oddzielające cechy on podgląda, on jest tak blisko, że prawie leży na piersi żydostwa. Jak mu nie wierzyć? Oto, co wreszcie mówi, na krótko przed śmiercią:

"Żydzi są najsubtelniejszym narodem W Europie"29. "[...] wszystko co europejskie jest niesłychanie gruboskórne, surowe, w porównaniu z tym, co żydowskie [...]"30. „Żydzi przynoszą świętą i wielką idę 'grzechu' (a ja płaczę), bez której nie istnieje religia [...]. Oni. Oni. Oni. Oni otarli smarki sławetnej europejskiej ludzkości ${ }^{31}$ i wręczyli jej modlitewnik: 'masz, bałwanie, pomódl się'. Oni dali psalmy. Madonna też jest Żydówką. Kim byśmy byli, gdyby nie Żydzi, jakimiż dzikusami w Europie" ${ }^{\prime 32}$. Socjalizm? Ale "przecież socjalizm wyraża ideę 'braterstwa narodów' i 'braterstwa ludzi', i tę ideę uznali oni za podstawę..." ${ }^{\prime 33}$.

Te słowa Rozanowa są takgłębokie, mimo ich pozornej płynności, prostoty i prostactwa, że odczytywać je, rozszyfrowywać można w nieskończoność. O czym jest tu mowa? Czy tylko o żydostwie? Czy aby nie o chrześcijaństwie - w pewnym sensie przeciw żydostwu i w związku z nim, albo w przeczuciu potencjalnego związku?

Ale nie będziemy przedłużać. Mimo wszystko Rozanow powiedział coś za bardzo wielu nie-Żydów: co im się w Żydach "podoba”, a co "nie podoba”. O żydowskiej pobożności, zamykającej usta, Rozanow także wiedział. Jest im trudniej niż nam, mówił; ale przecież można również zadać sobie trud i trochę wyrzec się siebie, jeśli nie rozumiemy. Wierzył, że "czegoś nie

29 В.В. Розанов, Апокалипсис нашего времени, w: idem, Избранное, ред. Е. Жиглевич, вступ. ст. Г. Штаммлер и Е. Жиглевич. А. Нейманис, Мюнхен 1970, s. 481 [przekład polski: W. Rozanow, Apokalipsa naszych czasów, przeł. W. Krzemień, Białystok, Łuk 2006, s. 49].

30 Tamże, s. 486 [przekład polski: W. Rozanow, Apokalipsa naszych czasów. ..., s. 55].

31 U Rozanowa: europejskiej ludzkości.

32 Tamże, s. 482 [przekład polski: W. Rozanow, Apokalipsa naszych czasów. ..., s. 50].

33 Tamże, s. 487 [przekład polski: W. Rozanow, Apokalipsa naszych czasów..., s. 56]. 
rozumiemy"; ale czy Żydzi naprawdę chcą, żebyśmy „zrozumieli” — nad tym się nie zastanawiał; sam przemawiał w ich imieniu, ale wnet zatrzymał się i zaczął „podpatrywać".

Tymczasem ta kwestia jest też ważna: nam nie-Żydom, w zdecydowanej większości, ciąży nasze oderwanie od żydostwa, gdziekolwiek by było rozważane i gdziekolwiek by się objawiło: od głębokiego porządku religijnego, korzennego, po drobne, na poły barbarzyńskie przejawy życia codziennego. Chcemy to wszystko wyjaśnić; wydaje się, że można porozumieć się w samych korzeniach, że można dojść do czegoś nowego, a wtedy to nowe da również nowe odbicie w życiu. Ale co, jeśli żydostwo wcale tego nie chce i wcale nie wierzy w takie możliwości? Wreszcie a co jeśli ono nas wcale nie potrzebuje?

To tylko pytanie, a nie założenie i nie „podglądanie": nie mam możliwości podglądania. A pytanie dotyczy jednego czasu teraźniejszego. Ponieważ w przyszłości dalekiej czy bliskiej, wszyscy do kwestii naszego możliwego związku z pewnością powrócimy. Na pewno będziemy jej szukać i - kto wie - czy w końcu jej nie znajdziemy? 